Acta medico-historica Rigensia (2020) XIII: 58-82

doi:10.25143/amhr.2020.XIII.04

Marcin Orzechowski, Maximilian Schochow, Florian Steger

\title{
Combatting Venereal Diseases as an Instrument of Politicised Medicine: Analysis on the Example of the Soviet Occupation Zone in Germany, the German Democratic Republic, and the Polish Peoples' Republic
}

\begin{abstract}
The programme for combatting venereal diseases in the Soviet Occupation Zone of Germany (SOZ), the German Democratic Republic (GDR) and the Polish Peoples' Republic (PPR) after the Second World War was adopted from the Soviet healthcare model. In order to maintain the spread of infections, both countries introduced specific legislation. The analysis of the regulations shows several similarities, such as establishment of easy access to anti-venereal health services, interruption of the chain of infection, and special treatment of individuals who constituted a danger of spreading the infection through compulsory hospitalisation. However, some differences are also visible. In the PPR, the decision about compulsory hospitalisation was left to individual evaluation of the attending physician. Closed venereology facilities or reformatories for treatment of venereal diseases, which existed in the GDR, were not established through legal regulations in the PPR. Since 1964, Polish law specifically targeted prostitutes and alcoholics as sources of spreading venereal diseases. These groups were not mentioned in the German legal acts. Analysis of praxis of compulsory commitment in the SOZ and GDR shows that mostly young women characterized as "drifters" were sent to closed venereology wards with breach of legal regulations. The number of prostitutes constituted only a very small fraction. In the PPR, the data from contemporary literature also indicates
\end{abstract}


a considerable number of young women, the so-called "drifters", committed to venereology ward.

Keywords: venereal disease, public health, legal regulations, history, German Democratic Republic (GDR), Polish Peoples' Republic (PPR).

\section{Introduction}

During the communist period, comprehensive trans-border cooperation between centres of venereal diseases control in socialist countries of the Eastern bloc took place. This resulted in a constant exchange of information about infected contacts as well as methods of combatting venereal diseases. ${ }^{1}$ The foundation for this cooperation was the similarity of the organisation, legal approach, and structures of the programmes of combating venereal diseases. The Polish Peoples' Republic (PPR), the German Democratic Republic (GDR), as well as other countries of the Eastern Bloc established health systems based on the Soviet healthcare model and introduced similar methods of combatting venereal diseases. ${ }^{2}$

The Soviet Union's programme, introduced after 1917, concentrated on early detection and treatment of the diseases among the population. Its main features were the mass examination of the population and compulsory treatment. Special emphasis was also put on active detection of the contacts combined with health and social education of the population in the spirit of the socialist society. ${ }^{3}$ Since the mid-1920s, the so-called prophylactories were set up in Moscow and other cities, where girls and women with venereal diseases or suspected of being ill were accommodated and cared for by specialists. Those who were forcibly admitted had to perform light factory work every day and were given general political lectures. ${ }^{4}$

1 Günter Elste, "Exchange of contact information between East Germany and other countries about persons infected with VD or at risk of infection," The British Journal of Venereal Diseases 52 (1976): 82-83.

2 E. Richard Weinerman, "The Organization of Health Services in Eastern Europe. Report of a Study in Czechoslovakia, Hungary and Poland, Spring, 1967," Medical Care 6 (1968): 267-279.

3 Oxana Kosenko \& Igor J. Polianski, “Der Tanz der kleinen Spirochäten. Theatrale Hygieneaufklärung und die Bekämpfung der Geschlechtskrankheiten in der frühen Sowjetunion," Urologe (February 2020): doi:10.1007/s00120-020-01133-9.

4 Henry E. Sigerist, Socialised medicine in the Soviet Union; with a foreword by Sidney Webb (London: V. Gollancz, 1937). 
Organisation of the all anti-venereal actions was to be centrally planned and conducted through health institutions on every administrative level of the state. ${ }^{5}$

Combatting venereal diseases in the PPR and GDR followed the Soviet model. ${ }^{6}$ Toward this goal, both countries introduced measures that can be analysed at two levels: (1) policy instruments included in legal acts in both countries, (2) individual procedures of commitment and treatment applied in medical institutions, especially venereology wards. These measures served not only as a means in fighting the transmission of venereal diseases but also aimed at realisation of a political programme towards particular groups of society. The goal of this programme was re-education of individuals into "socialist personalities" and consolidation of political power of the communist regime. To this end, combatting venereal diseases became instrument of action against people associated with behaviour unbecoming members of socialist society; and thus, an example of politicisation of medicine.

This is especially visible in the example of closed venereology facilities in the GDR. ${ }^{7}$ During the whole duration of the communist regime in the GDR, girls and women were compulsory committed, kept for a significant period of time, and subjected to involuntary medical treatment. As the majority of patients in these facilities were free of any venereal disease, it becomes clear that the primary objective of closed venereology facilities in the GDR was to educate them toward norm-conform citizens. During their detention, these women were somatically and psychologically traumatised. ${ }^{8}$

Therefore, the goal of this paper is to compare the legal framework and the praxis of compulsory commitment in the Soviet Occupation Zone (SOZ) in Germany, the GDR, and the PPR, in order to show similarities and differences between these two countries in the area of combatting venereal

5 P. V. Kozhewnikov, "Organization of syphilis control in the Soviet Union," The British Journal of Venereal Diseases 32 (1956): 229-230.

6 Florian Steger \& Maximilian Schochow, Disziplinierung durch Medizin. Die geschlossene Venerologische Station in der Poliklinik Mitte in Halle (Saale) 1961 bis 1982. $3^{\text {rd }}$ ed. (Halle (Saale): Mitteldeutscher Verlag, 2015).

7 Florian Steger \& Maximilian Schochow, "Closed Venereology Wards in the German Democratic Republic,” Acta medico-historica Rigensia 12 (2019): 67-91.

8 Florian Steger \& Maximilian Schochow, Traumatisierung durch politisierte Medizin, (Berlin: Medizinisch Wissenschaftliche Verlagsgesellschaft, 2016). 
diseases, as well as to demonstrate whether and how combatting venereal diseases in both countries underlain a political objective and constituted an example of politicised medicine.

For the purpose of this article, the existing research literature has been studied and evaluated. Extensive recent research work by the authors is available, especially for the situation in the SOZ and GDR, for which the care for venereal patients was reconstructed on the basis of eyewitness interviews and archive research. For the analysis of the situation in the PPR, legal texts were primarily evaluated. In addition to such normative texts, references to the practical implementation of the legal framework in the PPR could be found in the secondary literature. The praxis of compulsory commitment to venereology wards in the PPR presents a research desideratum, towards which this article is a first step.

This study consists of five parts. Following these preliminary remarks, the epidemiological situation concerning venereal diseases in East Germany and the PPR after the Second World War and during the communist period has been presented (Section 2). In the following steps, policy approaches aimed at combatting venereal diseases have been analysed (Section 3), with a particular focus on legislative measures towards particular social groups (Section 4). In the next section, based on selected examples of venereology wards in the PPR and the GDR, the praxis of compulsory commitment and treatment in these institutions have been studied (Section 5). The following part shortly introduces the situation in the selected countries of the East Bloc and Western European dictatorships and suggests some further research points (Section 6). Closing remarks conclude this paper.

\section{Epidemiological Situation Regarding Venereal Diseases after the Second World War until 1989}

Immediately after the end of the Second World War, the spread of venereal diseases, mostly syphilis and gonorrhea, escalated rapidly both in the PPR and SOZ. Destruction of healthcare infrastructure caused by military actions during the war, death of a significant proportion of healthcare personal, widespread criminal offenses as well as migratory movements of millions of people led to an increase in the incidence of venereal infections. According to the data from the year 1947, the number of people in Poland 
infected with syphilis amounted to over 500 cases per 100,000 population, for gonorrhea the number exceeded 240 cases per 100,000 population. ${ }^{9}$ This high rate of infections placed Poland in the top rank among European countries at the time. In the SOZ in Germany and later in the GDR precise numbers for the period 1945-1950 are unknown. Estimates provide the number of almost 1,000 cases, both syphilis and gonorrhea, per 100,000 population. ${ }^{10}$ After the implementation of the reporting obligation in 1950, the morbidity of the venereal diseases was observed at 67 and 150 cases per 100,000 people for syphilis and gonorrhea respectively. ${ }^{11}$

The hazard of the spread of venereal diseases constituted a serious problem in both countries during entire communist period. After the initial successes in containing the epidemic situation, a subsequent significant outbreak occurred during the 1950s and, on a much higher scale, in the 1960s. Poland observed a recurrence of contagions, which peaked in the early 1970s with morbidity of over 153 cases for gonorrhea and over 51 cases for syphilis per 100,000 people. Further years saw a steady decrease in the number of ill persons until the level of over 2 and 22 cases per 100,000 for syphilis and gonorrhea respectively in 1989. ${ }^{12}$ In the GDR since 1967, a significant rise in the number of reported patients with gonorrhea was observed and remained high until 1989. During its peak in 1980 , the morbidity reached over 300 cases per 100,000 people. In contrast, the spread of syphilis in this country was contained fairly quickly at the beginning of the 1960 s, and for the remaining 30 years it did not exceed 6 cases per 100,000 people. ${ }^{13}$

It is important to remark that these numbers, especially for the first postwar years, are predominantly estimates and they may not mirror the true

9 Józef Towpik, "Problems of Venereal Disease Control in Poland," The British Journal of Venereal Diseases 33 (1957): 78-79.

10 Uta Falck, VEB Bordell. Geschichte der Prostitution in der DDR (Berlin: Ch. Links Verlag, 1998).

11 Hans Philipp Pöhn \& Gernot Rasch, Statistik meldepflichtiger übertragbarer Krankheiten. Vom Beginn der Aufzeichnungen bis heute. Bundesgesundheitsamt: Bga-Schriften 5 (München: MMV Medizin Verlag, 1994), 46-48.

12 Jan Kostrzewski, Wiesław Magdzik \& Danuta Naruszewicz-Lesiuk, eds., Choroby zakaźne i ich zwalczanie na ziemiach polskich w XX wieku (Warszawa: Wydawnictwa Lekarskie PZWL, 2001).

13 Hans Philipp Pöhn \& Gernot Rasch, Statistik meldepflichtiger übertragbarer Krankheiten, 178-180. 
occurrence of venereal diseases in both countries. They may be distorted through false reports of disease incidence as well as an imprecise methodology of reporting and collecting the data. ${ }^{14}$ However, they illustrate the scale of the issue and temporal tendencies in disease occurrence. Moreover, they correspond with peaks in morbidity observed in other countries. ${ }^{15,16}$

\section{Legislative Measures for Combatting Venereal Diseases}

Breaking of the epidemiological spread of venereal diseases became one of the most important tasks of the authorities in both countries. As a result, several legal acts were issued. The importance of these laws shows the fact that they were among the earliest legal initiatives taken by both respective administrations after the war. In the following years, these regulations have been modified and supplemented in order to adjust policy to the current epidemiological situation.

The primary legislative measure regulating public and health administration's actions in combatting venereal diseases in the PPR was "Decree of April 16, 1946, regarding combating venereal diseases" (hereafter "Decree of April 16, 1946"). This legal act with changes from January 16, 1947, and July 27, 1949, was in force during the whole communist period and has been lifted only in the year 2001. It was complemented by several administrative acts issued by the Polish Ministry of Health, such as "Circular No. 7/48 of January 22, 1948, regarding combatting venereal diseases" (hereafter "Circular No. 7/48") and "Instruction of the Health Minister regarding compulsory hospitalisation of people with a venereal disease of June 21, 1951" (hereafter "Instruction of June 21, 1951"). Since the mid-1960s, "Regulation of the Minister of Health and Social Security Concerning Medical Examinations for Detecting Venereal Diseases" of September 2, 1964 (hereafter "Regulation of September 2, 1964") provided the main supplement of previous legislation and formally remained in force until 2003.

14 Andrzej Stapiński, Zwalczanie kiły i rzeżączki w Polsce (Warszawa, Wydawnictwa Lekarskie PZWL, 1979), 58-71.

15 R. R. Willcox, "A world-wide view of venereal disease," The British Journal of Venereal Diseases 48 (1972): 163-176.

16 Ambrose King, "Failure to Control Venereal Disease," The British Medical Journal, 1 (1970): 451-457. 
In the SOZ, the Weimar "Law on Combatting Venereal Diseases" from 1927 remained in force until 1947. Initially, early legislative measures issued by the Soviet Military Administration in Germany (SMAG) in the SOZ in form of Orders, supplemented this law. The first such Order, "Order No. 25" was issued on August 7, 1945. The following one, "Order No. 030" was introduced on February 12, 1946. The severity of the epidemiologic situation led to promulgation on December 11, 1947, of the "Order No. 273", which repealed the Weimar Law of 1927. This act retained its binding power after the transition of the SOZ into the GDR in 1949. Only at the beginning of the 1960s, the GDR's Ministry of Health issued its own act, the "Regulation for the Prevention and Control of Venereal Diseases of February 23, 1961" (hereafter "Regulation of February 23, 1961"), which remained in force until 1990.

A comparison of these regulations shows similarities in policy approach in both countries. These similarities are visible, in the first place in the regimentation of the organisation of venereal prevention, as well as examination and treatment of patients. In both countries, access to antivenereal services was guaranteed on every level of the country's administration. In the PPR, the "Decree of April 16, 1946" introduced hierarchical organisational structure, in which coordination of all actions lied within the competencies of the Ministry of Health and implementation of actions was to be conducted in healthcare institutions on district and county levels (§ 13-14). Anti-venereal services for the population were provided through a dense network of dispensaries and hospitals. In combatting the venereal diseases immediately in the post-war years, Polish health authorities concentrated on mass examination, treatment, and propaganda in course of the so-called "Action W". ${ }^{17}$ From 1948 to 1955, the so-called "mobile sanitary columns" visited areas particularly threatened with venereal diseases or remote from health centres and provided mass examinations and treatment, conducted health propaganda actions, and increased efficiency of local healthcare staff through training. A similar form of action was not conducted in the GDR.

17 Andrzej Stapiński, "Założenia organizacyjne zapobiegania, zwalczania i leczenia chorób wenerycznych na ziemiach polskich w XX wieku," in Choroby zakaźne i ich zwalczanie na ziemiach polskich wXX wieku, ed. Jan Kostrzewski, Wiesław Magdzik \& Danuta Naruszewicz-Lesiuk (Warszawa: Wydawnictwa Lekarskie PZWL, 2001), $117-122$. 
In the SOZ and GDR, a system of easily-accessible dispensaries was also created. SMAD “Order No. 25” regulated prevention, medical care, and compulsory treatment of venereal diseases. In particular, the provisions of this Order decreed the organisation of a dense network of medical facilities for the treatment of venereal diseases with a sufficient number of beds for patients as well as an increase in the number of venereology specialists (§3). All cases of venereal disease were to be reported to proper authorities. A special feature of the German system was the existence of reformatories under police guard, introduced through "Order No. 030" (§7). In these reformatories, individuals with venereal diseases, as well as persons who evaded medical treatment for venereal diseases and women who infected military personnel could be compulsorily treated. These facilities in several instances later evolved into closed venereology wards. ${ }^{18}$

A further point of similarities in policy approaches between both countries concerns reporting obligations and tracing of infection sources. In both countries, this task laid in the responsibility of the first-contact physicians reporting their findings to the health administration. In the authority of these organs laid responsibility for tracking possible contacts, their examination, and treatment. In order to fulfill this task, the medical authorities in both countries were to be supported by police officials. The importance of this point is highlighted by the fact that the obligation for contact tracing is repeatedly mentioned in almost all legal acts as well as in the literature on the topic from the period. ${ }^{19,20}$

Regulations of relevant legal acts in both countries foresaw compulsory examination and hospitalisation of individuals with venereal diseases, who constituted the danger of spreading the infection. In the PPR, the "Decree of April 16, 1946" ( $\$ 11)$ foresaw ordering the treatment of individuals with venereal diseases in one of the four forms: 1) therapy by a physician chosen by the patient; 2) treatment in a medical facility for general healthcare; 3) treatment in a venereology health centre, chosen by the regional healthcare administration; or 4) treatment in a hospital ward. Detailed instructions for admitting patients for treatment on an inpatient and outpatient

18 Florian Steger \& Maximilian Schochow, Traumatisierung durch politisierte, Medizin, 14-16.

19 Günter Elste, Exchange of contact information, 82.

20 Józef Towpik, "Critical evaluation of the venereal disease control campaign in Poland 1970-76,” The British Journal of Venereal Diseases 55 (1979): 127-130. 
basis were to be provided in separate regulations. Such directives were issued by the Ministry of Health in the "Circular No. 7/48". According to it, the choice of the form of treatment was within the responsibility of a district physician. The decision about sending a patient to an outpatient or inpatient treatment should be taken with regard to its purposefulness. More detailed "Instruction of 21st June 1951" (§2) identified categories of persons with venereal diseases that were subjected to compulsory hospitalisation. Among these were: 1) persons that posed a danger of spreading infection because of their poor housing conditions; 2) persons that did not follow treatment recommendations thus extending the period of the treatment; 3) persons for which hospitalisation would ensure rapid recovery and return to employment; and 4) persons that required particular examination or treatment methods.

Compulsory hospitalisation of individuals with venereal diseases was also an object of regulations in the SOZ and the GDR. Already in the early months after the end of the war, the SMAD "Order No. 25" provided that individuals with infectious forms of venereal diseases, especially syphilis, should be compulsory hospitalised. Subsequent regulations broadened the target group and sharpened the application. Following the prescripts of "Order No. 273" (§14), all persons with venereal diseases that did not follow the instructions of the attending physician, had sexual contacts against the rules of the Order, broke off the hospital treatment or, based on their lifestyle, could be suspected of spreading the venereal diseases, were subjected to compulsory treatment in a closed hospital. With the introduction of the GDR's own regulations in February 1961, such a direct referral for compulsory hospitalisation was replaced with a three-step procedure ( $\$ 20)$. According to this regulation, compulsory referral to a closed institution could only occur after the patient did not comply with the outpatient or stationary treatment. Therefore, since 1961, legally a person could be committed to a closed venereology ward only as a last measure if the previous steps - outpatient and stationary - did not prove to be effective. In praxis, this rule was often ignored or violated..$^{21}$

Therefore, it is noticeable that compulsory hospitalisation in the case of venereal disease was applied in both countries. Differences between the PPR and the SOZ/GDR are observable in the prescribed procedures.

21 Florian Steger \& Maximilian Schochow, Traumatisierung durch politisierte Medizin, $114-118$. 
Whereas in the GDR, the three-step procedure was an administrative process that was built on top of each step, regulations in the PPR provided physicians with options as to the relevant treatment procedure. In his decision, the physician could orient himself only on his assessment of appropriate measures. Compulsory hospitalisation was only vaguely prescribed for individuals that constituted a threat for spreading the infection. This provided a wider margin of doctor's personal judgment. Moreover, contrary to the SOZ and GDR, the institution of closed venereology wards was not specifically mentioned in the Polish legislation.

\section{Approach Towards Particular Groups of Society}

The issue of control of venereal diseases in both countries was closely related to perceived moral problems of the socialist society: sexual promiscuity, alcoholism, lack of socialist morals and work ethics, as well as the discipline of the youth. On the ideological level, these phenomena were associated with a behavior unbecoming a member of a socialist society. In this respect, medicine obtained an important role. Combatting the spread of venereal diseases became closely connected to the matter of civic education of the citizens of a socialist state, eradication of socially unwanted behavior, or, as it was the case in the GDR, to the creation of a "socialist personality". 22

\subsection{Prostitutes}

Legislative acts referring to combatting venereal diseases in both countries played an important role towards this goal. They targeted individuals that did not follow the rules prescribed for socialist citizens and introduced measures aimed at controlling unwanted behaviour. In this context, especially in the PPR, the matter of prostitution received particular attention. According to the dominant ideological view on the socialist society of the time, prostitution was mainly a consequence of poverty and discrimination of women. In a socialist society, women could easily find other sources of income and did not have to resort to prostitution. Women that did not comply with the role determined for them were to be disciplined and reeducated. ${ }^{23}$ Such a view is especially visible through the analysis of regulations referring to this particular group.

22 Florian Steger \& Maximilian Schochow, Traumatisierung durch politisierte Medizin, 114-118.

23 Henry E. Sigerist, Socialised medicine in the Soviet Union. 
Initial legal regulations in both countries specifically targeted prostitutes as sources of venereal diseases and aimed at suppression and isolation of this group. In the case of the SOZ, Orders of the SMAD No. 25, No. 030, and No. 273 sanctioned prostitution and created special care facilities, the so-called reformatories ("Fürsorgeheime"). In these reformatories, prostitutes and women who infected Soviet military personnel with venereal diseases were to be compulsorily treated but should also receive vocational education. In addition, job creation schemes for women without income were established. Furthermore, prostitutes and individuals with numerous sexual partners could be sentenced to detention in a "workhouse" or a "work colony". The GDR "Regulation of February 23, 1961" did not specifically mention the term "prostitution" in its provisions. This regulation differentiated between "persons suspected of being infected" and persons "strongly suspected of being infected with venereal diseases" (§3). This second category included individuals that repeatedly infected others with a venereal disease or had frequently changed sexual partners.

The term "prostitution" did not reappear in GDR legislation until 1968. The GDR Criminal Code, which came into force on July 1, 1968, introduced the so-called "anti-social clause" (§ 249). It stated, among other things: "(1) Anyone who endangers the social coexistence of citizens or public order by stubbornly avoiding regular work out of aversion to work, even though he is capable of work, or who engages in prostitution or otherwise unfairly procures means of subsistence, shall be punished by a suspended sentence or by imprisonment, work education or imprisonment for up to two years." 24 The new version of the Criminal Code of 28 June 1979 also made "prostitution" a punishable offence: "(2) Similarly, anyone who engages in prostitution or in any other way impairs public order and security by engaging in an antisocial lifestyle shall be punished." 25,26

24 "Strafgesetzbuch der Deutschen Demokratischen Republik - StGB - vom 12. Januar 1968," [Penal Code of the German Democratic Republic of January 12, 1968], Gesetzblatt der DDR, Teil 1, Nr. 3: 97-105.

25 "Strafgesetzbuch der Deutschen Demokratischen Republik - StGB - vom 28. Juni 1979" [Penal Code of the German Democratic Republic of June 28, 1979], Gesetzblatt der DDR, Teil 1, Nr. 17, S. 139-146.

26 Sven Korzilius, "Asoziale” und "Parasiten" im Recht der SBZ/DDR. Randgruppen im Sozialismus zwischen Repression und Ausgrenzung (Köln, Weimar, Wien: Böhlau, 2005). 
In the legal system of the PPR, prostitution was not explicitly mentioned in the period between 1947 and 1964. Initial designation of prostitutes as the source of venereal infections was removed through novelisation of the "Decree of April 16, 1946" (§ 10.3) on January 16, 1947, instead referring to individuals who threaten to spread venereal diseases. However, the issue of prostitution continuously was perceived as relevant for improving the moral stance of the society. As soon as the mid-1950s, prostitution again moved forward into the focus of legislators. Several actions targeted prostitutes. Names and addresses of women engaged in prostitution were gathered and passed on to the organs of administration and police. Other solutions were also proposed, among them, the creation of a central register of women suspected of prostitution that should be subjected to regular specialist examinations or establishment of the so-called transitional houses, in which women could live until they found employment. ${ }^{27}$

However, these administrative proposals were never implemented. Instead, the question of prostitution remained within the authority of health services. Compulsory examination and hospitalisation continued to be the main instruments in controlling prostitution, especially as prostitution was not a criminal offense in the light of the Polish Penal Code. In cooperation with the members of the police force ("Civic Militia"), health authorities had to observe a strict regime of treatment for prostitutes comprising suspicion, diagnosis, and treatment in a hospital ward. ${ }^{28}$ On the legislative level, the problem of prostitution with regard to venereal diseases was anew regulated by the "Regulation of September 2, 1964". This act reintroduced the term "persons engaging in prostitution" $(\S 1.3)$ and decreed that every person suspected of prostitution by the Civic Militia was to be subjected to compulsory medical examination and treatment in a hospital ward.

\subsection{Alcoholics}

Further social phenomenon closely associated with spreading venereal diseases was alcoholism. In the PPR, the specific actions targeting intoxicated individuals as possible sources of venereal diseases were defined in the "Regulation of September 2, 1964" (§ 1.4). Alcoholics detained in a detoxification centre more than once in two months were to be subjects

27 Bogumiła Kempińska-Mirosławska \& Agnieszka Woźniak-Kosek, "Health policy regarding the fight against veneral diseases in Poland in the years 1945-1958," Military Pharmacy and Medicine VI (2013): 49-72.

28 Ibid., 63-64. 
of compulsory examination for venereal diseases and stationary treatment. This regulation was influenced by the opinion that alcoholics were especially susceptible to being infected with venereal diseases, they constituted a group of demoralised individuals, and they displayed "un-socialistic" behaviour. As a result, it was decided that the combined fight against alcoholism and venereal diseases would bring more benefits compared to separate activities. Structures of the police force were supposed to join the anti-venereal action by commencing close cooperation with doctors of venereology clinics, particularly in earlier detection of sources of infection among prostitutes, sexually promiscuous persons, and alcoholics. ${ }^{29}$

The aim of the anti-venereal medical institutions comprised besides treatment of the disease - isolation, eradication of the socially unwanted behaviour, and education of demoralised individuals. The Polish "Regulation of September 2, 1964" constitutes a clear example of these policies. As an answer to the increased number of infections with gonorrhea at the beginning of the 1960s, the Polish Ministry of Health introduced legislation specifically targeting particular groups: prostitutes and alcoholics. Similar actions against alcoholics were not included in the laws to combat venereal disease in the GDR.

\subsection{Drifters}

Thus, legal regulations on combatting venereal diseases specifically prescribed actions against individuals infected with venereal diseases, and, in the case of the PPR, against specific groups such as prostitutes and alcoholics. However, especially since the 1960s, also persons accused of vagrancy or so-called "drifting" were increasingly committed to venereology wards, especially in the GDR, with breach of regulations in force.

This can be corroborated by data concerning the status of individuals committed to compulsory hospitalisation in both countries. In their research, Schochow and Steger analysed archival records of 1,241 patients from the reformatory, which later became a closed venereology ward for women Leipzig-Thonberg. ${ }^{30}$ These two institutions functioned between 1946 and 1990 and were one of the main institutions for compulsory

29 Wojciech Rost, "Pijaństwo i choroby weneryczne pod obstrzałem dzielnicowej służby zdrowia ," Stużba Zdrowia 40 (1957): 1-11.

30 Maximilian Schochow \& Florian Steger, "Die Patientenakten der geschlossenen Venerologischen Einrichtungen Leipzig-Thonberg (1946-1990),” Medizinhistorisches Journal 53 (2018): 98-124. 
treatment in the GDR. There are documented statements in the patient records about characteristics of the committed women. In the period between 1946 and 1961, when the SMAG Orders were in force, only $3 \%$ of all committed women were characterised as prostitutes. $13 \%$ were sexually promiscuous persons and $6 \%$ were women characterised as "female drifters"; that is, individuals who avoided regular work or vagrants. The majority of the committed (75\%) constituted women with venereal diseases. The data from the period 1961-1990, when the "Regulation of February 23, 1961" was in force, presents a different picture. During that time, the number of committed women under the claim of prostitution remained very low (3\%). The largest group constituted girls and women characterised as "female drifters" (52\%). The numbers of women with venereal diseases and sexually promiscuous women, compulsory committed to Leipzig-Thonberg were significantly lower, only $32 \%$ and $9 \%$ respectively. This shows that women characterised as prostitutes were a very small minority among the total number of women committed to this institution. ${ }^{31}$ It becomes clear that the claim that in particular prostitutes were forcibly committed to the closed venereology facilities of the SOZ or the GDR is not tenable. These results indicate also that the normative framework conditions were disregarded and in practice, above all, the socalled "drifters" were forcibly committed.

Comparing characteristics of committed women in the PPR, it is important to mention methodological differences in obtaining the results. Characteristics of women committed to the ward Leipzig-Thonberg was researched based on archival patient records. Similar patient records from the PPR have not yet been researched, the accessible data is derived from secondary literature. Therefore, its reliability cannot be independently confirmed. However, information acquired from Polish secondary literature on the topic shows a resemblance to these results. One venereology ward for women in Szczecin reported that in the years 1969 to 1973, only about $15 \%$ of the women committed to this facility were characterised as prostitutes. $22 \%$ of the total number constituted women that refused treatment and $21 \%$ of girls were committed for vagrancy and the so-called "drifting".

31 Maximilian Schochow \& Florian Steger, "Zwangseingewiesene Mädchen und Frauen in Venerologischen Einrichtungen waren keine Prostituierten," Deutschland Archiv 20.01.2020. https://www.bpb.de/geschichte/zeitgeschichte/deutschlandarchiv/303823/ zwangseingewiesene-maedchen-und-frauen-in-venerologischen-einrichtungen. 
Numerically the largest group was women with venereal diseases committed by an outpatient clinic (42\%). ${ }^{32}$

Committing women and girls in the GDR under the pretense of "drifting" clearly shows that venereology facilities there did not have a character of only medical institutions but also served as an establishment for "correction" of unwanted behaviour. Neither the PPR's nor the GDR's regulations explicitly mentioned vagrancy or avoiding regular work as a reason for committal to a venereology facility. Such a procedure constituted a clear breach of law. Unlawful commitments to the closed venereology ward Leipzig-Thonberg were even an object of criminal investigation and official complaint lodged by the public prosecutor's office in Leipzig in 1964: "As a public prosecutor, I have to point out in the context of legal supervision, that the unlawful state of the general admission of patients and those suspected of being ill to a closed institution is not permitted." 33 Following the investigation, the closed venereology ward was to be closed; however, the resistance of medical administrators of the ward led only to a change of administrative supervision of the institution. The praxis of unlawful committal to the ward continued. ${ }^{34}$

\subsection{Men}

Among individuals committed to closed wards in the GDR, the dominant group constituted of girls and women. Although regulations in force did not distinguish between the sex of the persons who should be apprehended and subjected to treatment, men were very seldom committed. Patients' records from the Medical Academy in Erfurt from 1953 to 1970 show that among more than 3,100 inpatients only $190(6 \%)$ were men. ${ }^{35}$ Similar data from three facilities in Berlin, Dresden, and Erfurt for the year 1968 reveal that committed men constituted a clear minority only $19 \%$ of the total number. Mostly, these were heterosexual men, only a very small fraction of the patients were homosexuals. Closed venereology

32 Ludmiła Kubicka, Irena Holzer \& Danuta Osipowicz, "Epidemiologia rzeżączki u kobiet w woj. Szczecińskim ," Przegląd dermatologiczny 1 (1977): 79-83.

33 Maximilian Schochow \& Florian Steger, Traumatisierung durch politisierte Medizin, 116.

34 Ibid., 118.

35 Maximilian Schochow \& Florian Steger, "Männer in geschlossenen Venerologischen Stationen der DDR am Beispiel von Berlin, Dresden und Erfurt," Gesundheitswesen (Juli 2020): doi:10.1055/a-1186-0075. 
wards for men were part of closed venereology facilities, each of which included a ward for women. Men and women were accommodated separately. Reasons for the admission of men were sexually transmitted diseases to be treated, suspicion of frequently changing sexual partners, and disciplinary measures.

Research shows that men in the GDR were much less affected by compulsory commitments to closed venereology wards. This fact was justified with three reasons. Firstly, men were to be more reliable than women in treatment of venereal diseases. Secondly, men were to be less promiscuous than women. And thirdly, men should be protected from mental burdens of a compulsory commitment. ${ }^{36}$ In contrast, women were seen by venereology doctors in the GDR as delinquent and unreliable, which is why they were more often committed.

\section{Praxis of Compulsory Commitment to Venereology Wards}

In both countries, venereology wards were established for the compulsory treatment of venereal diseases. Such wards existed in all districts of the GDR ${ }^{37}$, and all administrative provinces of the PPR. ${ }^{38}$ Based on examples of three such wards in both countries - the closed venereology wards in Halle (Saale) and Leipzig-Thonberg in the GDR and the dermatological and venereology ward in Szczecin in the PPR - the following passages aim to present the praxis of admission to these wards and analyse it in the light of the legislation from the time.

Closed venereology ward for women in Halle (Saale) was founded in 1961 and functioned until 1981. Venereology ward Leipzig-Thonberg emerged from a reformatory for patients with venereal diseases, founded in 1946, and since 1952 functioned as a closed ward. It existed until 1990. The functions of the wards were outlined in the respective house regulations; their main aim was to isolate and provide treatment for individuals

\footnotetext{
36 Maximilian Schochow \& Florian Steger, "Männer in geschlossenen Venerologischen Stationen der DDR am Beispiel von Berlin, Dresden und Erfurt," Gesundheitswesen (Juli 2020): doi:10.1055/a-1186-0075.

37 Maximilian Schochow \& Florian Steger, "Closed venereology wards in the GDR," Journal of the European Academy of Dermatology \& Venereology 30 (2016): 1814-1818.

38 Józef Towpik, "The Situation in Eastern Europe," The British Journal of Venereal Diseases 52 (1976): 110-112.
} 
with venereal diseases. Girls and women of various age, from 13 to more than 70 years old, were committed to the ward. The reasons for commitment were diverse: suspicion of loitering, accusation of prostitution, renunciation of medical examination and treatment, or vagrancy. ${ }^{39}$ Especially this last ground served as the main reason for committal of young girls that were on the run from the parents' home. Frequently they were taken into custody on railway and bus stations by the police force and delivered directly to the ward.

In other instances, the denouncement as a highly promiscuous person was enough for detention in the ward. The procedure of admission often involved psychical and physical traumatisation for the patients. The girls and women were subject to institutionalised terror from the personnel of the institution and to torment by other female patients. Formalised system of punishments and rewards as well as the informal hierarchical order among the patients served the purpose of disciplining the women and their reeducation in terms of the socialist values. ${ }^{40}$

Dermatological and venereology ward for women in Szczecin was established in 1945 and existed through entire socialist period. During the time, the ward was a part of the Szczecin District General Hospital. The praxis of admission to the ward has not been yet investigated in detail; however, indications of its illicit character can be found in the secondary literature. ${ }^{41}$ Between 1969 and 1973, 366 women with gonorrhea were hospitalised in the ward. ${ }^{42}$ The majority of these were women (58\%) were brought for compulsory treatment by the police. The youngest patients were 14 years old. As noted by the attending physicians, despite their young age, the adolescent girls were characterised by high promiscuity. They were often on the run from the parents' home or without a permanent residence.

39 Maximilian Schochow \& Florian Steger, "Closed venereology wards in the GDR", Journal of the European Academy of Dermatology \& Venereology 30 (2016), 1815.

40 For more detailed description of the procedure of admission, treatment, and terror on the wards see: Florian Steger \& Maximilian Schochow, "Closed Venereology Wards in the German Democratic Republic," Acta Medico-Historica Rigensia XII (2019): 67-91; Maximilian Schochow \& Florian Steger, "Closed venereology wards in the GDR”, 1814-1818; Florian Steger \& Maximilian Schochow, Disziplinierung durch Medizin, 107-153; Florian Steger \& Maximilian Schochow, Traumatisierung durch politisierte Medizin, 114-141.

${ }^{41}$ Ludmiła Kubicka, Irena Holzer \& Danuta Osipowicz, Epidemiologia rzeżączki u kobiet, $79-83$.

42 Ibid., 79. 
During the time, they allegedly maintained sexual contacts with port workers and sailors. They were brought to the hospital ward by the officers of the police force, social workers, or in some cases, by their parents. At the time, the majority of the hospitalised girls (67\%) did not attend any school or work training. This fact, as well as high morbidity in the group of young patients, let to concerns among attending physicians as to the moral stance of adolescents and their social upbringing.

In comparison of venereology wards exemplified here, it is important to highlight the reliability of the data. Similarly to the case of characteristic of individuals committed, the history, functions, and daily life in the wards in Halle (Saale) and Leipzig-Thonberg have been researched through analysis of archival material and during interviews with contemporary witnesses. Therefore, the results provide very reliable insights into the commitment praxis and daily life at these wards. Similar research has not yet been conducted in Poland, and the data is based on the analysis of secondary literature on the topic. This puts in question the issue of reliability of the sources. However, even based on the sources from secondary literature, one can trace parallels between these wards, with regard to the procedure of commitment.

In these institutions, both in the GDR and the PPR, adolescent girls and women were compulsorily treated for venereal diseases. The patients could be as young as 13 or 14 years of age. Majority of the patients were escorted to the ward by the police. Among the reasons for detention in the ward, suspicion of prostitution, loitering, and vagrancy were most prominent, although a part of the patients was referred to the wards by organs of health administration. In the case of the closed wards in Halle (Saale) and Leipzig-Thonberg, compulsory detention in several cases occurred with violation of the binding three-step procedure for the commitment. The form of the referral to the venereology ward in Szczecin, still needs to be researched in detail, especially taking under consideration statements of contemporary witnesses. However, the method described in the literature - arrest and immediate commitment to the ward - would also suggest a breach of current legal procedures, especially of the "Circular No. 7/48" and the "Instruction of 21 June, 1951". During the stay in wards of Halle (Saale) and LeipzigThonberg, girls and women were subjected to the process of reeducation into "socialist personalities". Record of similar policy towards the patients in the Szczecin ward could not be found in the literature. 


\section{Combatting Venereal Diseases in Europe - Further Research Perspectives}

Comparison of combatting venereal diseases as an instrument of politicised medicine in the SOZ/GDR and the PPR is only a part of a much wider perspective. It can be assumed that similar legislative framework and praxis of compulsory commitment were implemented in other European countries, especially dictatorships with highly centralised healthcare systems that emphasised the moral stance of the society, accented higher importance of society over the individual, and showed little concern for democratic values and personal rights. In this context, research in East-East and East-West perspectives could address the relationship between medicine and politics in European countries. ${ }^{43}$

The Eastern European perspective on the history, goals, and functions of anti-venereal policy and venereology wards can be justified by a comprehensive redesign of the health systems in Eastern Europe based on the Soviet model. From previous research, it is known that after the end of the Second World War the health system of the USSR was established in the Eastern European countries, as was recently shown by the example of psychiatry. ${ }^{44}$ Reformatories for patients with venereal diseases and closed venereology wards in the SOZ and the GDR were a part of a comprehensive remodelling of the healthcare according to the Soviet example. The SMAG-Orders for combatting and containment of venereal diseases were in most parts translations of regulations of the Soviet healthcare system. ${ }^{45}$ Therefore, a worthwhile research perspective would constitute an investigation of the praxis of compulsory commitment to venereal facilities in the Soviet Union itself as well as in the countries that were a part of it, especially European countries: Belarus, Estonia, Latvia, Lithuania, Moldova, Ukraine.

Another research perspective provides an investigation of the legal framework and praxis of treatment of venereal diseases in other countries of the Soviet Bloc. Evidence suggesting the politicisation of healthcare in the area of combatting venereal diseases can be found in several of these

${ }^{43}$ Maximilian Schochow, Karen Bjoernsgard, Marcin Orzechowski \& Florian Steger, "Closed venereology wards in postwar Hamburg," Journal of the European Academy of Dermatology \& Venereology (2020), doi:10.1111/jdv.16237.

${ }^{44}$ Mat Savelli \& Sarah Marks, eds., Psychiatry in communist Europe (Basingstoke and New York: Palgrave Macmillan, 2015).

45 Florian Steger \& Maximilian Schochow, Traumatisierung durch politisierte Medizin. 
countries, among others in Czechoslovakia and Hungary. In Czechoslovakia, one of the consequences of the Second World War was a dangerous epidemiological situation regarding venereal diseases. ${ }^{46}$ As in other communist countries, ideas of the Soviet Union's health care model was appropriated to the health care situation in Czechoslovakia. In order to stem the spread of venereal diseases, a nation-wide anti-venereal campaign was introduced. It included mandatory tracing of sources and contacts. ${ }^{47}$ The results of the campaign brought a significant decrease in cases of syphilis and gonorrhea. Two legal acts in Czechoslovakia were of particular importance: the 1949 "Act on the Fight against Venereal Diseases" and the 1966 "Act on the Care of National Health". According to the first one, doctors were obligated to inform local administrative organs about detected venereal infections and investigate the origin of the infections. The second legal act allowed forced medical checks, and treatment in quarantine, if necessary, of persons suspected of having a sexually transmitted disease, especially prostitutes. From 1956 onwards, in Czechoslovakia, prostitution was considered to be against socialist morality, and treated as a serious corruption of the society. ${ }^{48}$

In Hungary, after the Second World War, the number of venereal infections was exceptionally high. One of the main reasons was the high number of rapes inflicted by the soldiers of the Soviet Army on Hungarian women. From 1945, Hungarian system was based on the Soviet epidemiological model with the inclusion of the pre-war ideas on controlling the spread of epidemic. ${ }^{49}$ Therefore, the emphasis on combating venereal diseases has been put on contact-tracing and follow-up examinations of persons at risk. The legal framework foresaw compulsory testing and hospitalisation, especially of "risk groups", such as sexually promiscuous persons. The "Legal decree No. 40.777" of 1945 provided basis for compulsory commitment of

46 V. Resl \& M. Kumpova, "Interaction of legislation and prevalence of sexually transmitted diseases with focus on syphilis and gonorrhea in the Czech Republic - review to year 2003," Journal of European Academy of Dermatology and Venereology 19 (2005): 692-695.

47 E. Hegyi \& G. Hudakova, "Problems of the campaign against the venereal diseases in Czechoslovakia,” The British Journal of Venereal Diseases, 36 (1960): 128-132.

48 Barbara Havelkova, "Blaming all Women: On Regulation of Prostitution in State Socialist Czechoslovakia,” Oxford Journal of Legal Studies 36 (2016): 165-191.

49 Viktoria Varkonyi, Timea Tisza, Attila Horvath, Terez Takacsy, Margit Berecz, Gyorgy Kulcsar \& Miklos Sardy, "Epidemiology of syphilis in Hungary between 1952 and 1996," International Journal of STD \& AIDS 11 (2000): 327-333. 
persons who stopped medical treatment or did not follow the requirement for treatment of venereal disease. Further legal acts, such as the "Legal decree 1951/82" of 1951 or the "Directive of the Director of the Budapest Police Committee 3/1964" of 1964 constituted the basis for the control and treatment of prostitutes suspected of being infected with venereal diseases. ${ }^{50}$

Forms of politicised medicine can also be evidenced in Western European dictatorships; for example, in António de Oliveira Salazar's dictatorship of Estado Novo in Portugal (1930s to 1974) and the Francisco Franco's dictatorship in Spain (1936/39 to 1977). In both countries, medicine was subjected to an ideology of the paternalistic dictatorial regime. ${ }^{51}$ The welfare policy of Estado Novo combined charitable elements with elements of a repressive nature, generating a model influenced both by the Catholic Church and the Public Security Police. ${ }^{52}$ The Ministry of Interior was responsible for projects in the domains of public health as well as internal security, which created an overlap of these two areas. The community, expressed as a centrally controlled state, served as a paradigm of moral regeneration of the social fabric and re-socialisation of individuals who were classified as health and moral hazard for the society. ${ }^{53}$

In Franco's dictatorship in Spain, healthcare was conceived as an instrument for political proselytism of the norms of the right-wing ideology. ${ }^{54}$ The main tasks of medicine were the provision of efficient care, the production, and the reproduction of the workforce, and work towards a moral renewal of the society. ${ }^{55}$ Special concern was concentrated on individuals

50 Viktoria Varkonyi, Timea Tisza, Attila Horvath, Terez Takacsy, Margit Berecz, Gyorgy Kulcsar \& Miklos Sardy, "Epidemiology of syphilis in Hungary between 1952 and 1996," International Journal of STD \& AIDS 11 (2000): 327-333.

51 Ursula Prutsch, Iberische Diktaturen. Portugal unter Salazar, Spanien unter Franco (Innsbruck: Studien Verlag, 2012).

52 Susana P. Bastos, O Estado Novo e os seus vadios. Contribuições para o estudo das identidades marginais e da sua repressão (Lisboa: Etnográfica Press, 1997).

53 Paula M. Page, Políticas de Saúde Portugesas 1940-1990: Consolidação de um Novo Regime de Poder entre a Intenção da Mudanca e os Limites da Continuidade (Coimbra: Univesity Dissertation, 1998).

54 Alfredo Menéndez-Navarro, "Occupational Health in the First Francoism, 1939-1953," in At Work in the World: Proceedings of the Fourth International Conference on the History of Occupational and Environmental Health, ed. Paul D. Blanc and Brian Dolan (San Francisco: University of California Medical Humanities Press, 2012), 93-97.

55 Carmen Moline Ro \& Pere Ysàs, "Workers and Dictatorship: industrial growth, social control and labour protest under the Franco regime, 1939-76," in Red Barcelona. 
considered "socially dangerous" - that presented a potential risk of behaviour transgressing official moral norms. Official legislation targeted individuals deemed as moral hazard. Especially homosexual behaviour and prostitution were regarded as explicitly dangerous because they carried a risk of spreading both moral corruption and sexually transmitted diseases. ${ }^{56}$

These examples of combatting venereal diseases in several countries with dictatorship political systems show significant similarities. All these countries introduced a legal framework, whose goal was not only controlling the spread of venereal infections but targeting individuals non-conforming to moral ideals of the state or dominating ideology. Whereby, as the abovementioned examples show, there were no substantial differences between the left-wing ideology of socialist states or the right-wing ideology of nationalist regimes in Portugal or Spain. Medicine in dictatorships was conceptualised as a political instrument that, among others, should serve the political goal of isolating and re-educating "morally corrupt" people towards state-prescribed norms and behaviour. Therefore, further research on the topic of politicised medicine should consider its functions and consequences in European, or even global, comparison. Such a comparative approach makes it possible to describe similarities and differences between the concept and the praxis of politicised medicine in various systems and countries and to make statements about its functions and exercise.

\section{Conclusion}

The approach towards venereal diseases in East Germany and the PPR during the communist period had two objectives. In the immediate period after the Second World War, it aimed at the control and eradication of the epidemic spread of venereal diseases. Since the beginning of the 1960s, perceived moral aspects of the socialist society - sexual promiscuity, alcoholism, and loosening of moral norms - moved into the focus. In the case of the PPR, legal norms from this period targeted prostitutes and alcoholics.

Social Protest and Labour Mobilization in the Twentieth Century, ed. Angel Smith (London and New York: Routledge, 2002), 185-205.

56 Alvar M. Vidal \& Antoni A. Donat, "Homosexuality, psychiatry and legal medicine in Franco's regime and Democratic Transition in Spain (1936-1979)," in Citizens, courtrooms, crossings. Conference proceedings, ed. Astri Andresen, Tore Grønlie, William Hubbard, Teemu Ryymin \& Svein Atle Skålevåg (Bergen: Rokkansenteret, 2008), 107-118. 
Compulsory examination and hospitalisation became one of the instruments towards controlling unwanted behaviour. In the GDR, explicit denomination of these groups was not included in the legal framework.

However, the praxis of commitment and daily life at the closed venereology wards shows course of action against non-conforming groups, especially young female drifters. Compulsory hospitalisation in many cases occurred with breach of legal regulations. Based on internal regulations of these facilities, the so-called "house rules", women committed to venereology wards were submitted to a systematic procedure of re-education into "socialistic personalities" through unnecessary medical interventions and daily terror. Examples of similar re-education measures in the PPR are yet unknown. In the GDR, praxis of compulsory commitment was mostly directed towards women characterised as "drifters", i.e. vagrants or without permanent work. Prostitutes in the GDR constituted only a very small percentage of patients and men were very seldom committed to the wards. Similar measures in the PPR are indicated in the secondary literature; however, still need to be researched in detail. Through such measures, combatting venereal diseases became instrument of politicised medicine, which should also serve for consolidation of the political power of the communist regime.

Politicisation of medicine can be paralleled to other European dictatorships. A comparison of approaches towards combatting venereal diseases and towards particular non-conforming groups of society considered as "socially dangerous" in an East-East and East-West perspective constitutes a research desiderate for further investigations on the topic.

\section{Venerisko slimību apkarošana kā politizētās medicīnas instruments padomju okupācijas zonā Vācijā, Vācijas Demokrātiskajā Republikā, un Polijas Tautas Republikāa}

\section{Kopsavilkums}

Venerisko slimību apkarošanas programma Vācijas padomju okupācijas zonā, Vācijas Demokrātiskajā Republikā, un Polijas Tautas Republikā pēc Otrā pasaules kara tika pārņemta no padomju veselības aprūpes modeḷa. Lai ierobežotu izplatību, abās valstīs ieviesa īpašu likumdošanu. 
Pastāvēja vairākas līizības, piemēram, viegla piekḷuve veselības pakalpojumiem, kas vērsti uz venerisko slimību profilaksi, infekcijas izplatības ķēdes pārtraukšana un īpaša to personu ārstēšana, kuras rada infekcijas izplatīšanās draudus, šādas personas hospitalizējot piespiedu kārtā. Tomēr saskatāmas arī atškirīibas. Polijas Tautas Republikā lēmumu par hospitalizāciju pieṇēma ārstējošais ārsts. Valsts likumdošana neparedzēja slēgtās venerisko slimību iestādes vai labošanas iestādes venerisko slimību ārstēšanai, kādas pastāvēja Vācijas Demokrātiskajā Republikā. Kopš 1964. gada Polijas likumdošanā kā venerisko slimību izplatīšanas avots tika minētas prostitūtas un alkoholiķi, kas savukārt Vācijas tiesību aktos nebija minēti. Analizējot piespiedu ārstēšanas praksi padomju okupācijas zonā Vācijā, Vācijas Demokrātiskajā Republikā, tika noskaidrots, ka slēgtās venerisko slimību nodaḷās tika ievietotas galvenokārt jaunas sievietes, kuras tika dēvētas par "klaidonēm”. No tām prostitūtas bija pavisam neliela daḷa. Mūsdienu dati liecina, ka Polijas Tautas Republikā ievērojams skaits jaunu sieviešu, tā saukto klaidoṇu, tika ievietotas venerisko slimību nodaḷās.

Atslēgvārdi: veneriskās slimības, sabiedrības veselība, tiesiskais regulējums, vēsture, Vācijas Demokrātiskā Republika, Polijas Tautas Republika.

\section{Secinājumi}

Venerisko slimību apkarošanai Austrumvācijā un Polijas Tautas Republikā komunisma periodā bija divi mērḳi. Uzreiz pēc Otrā pasaules kara mērķis bija kontrolēt, izskaust un nepieļaut venerisko slimību izplatīšanos. Savukārt kopš 20. gadsimta 60. gadu sākuma uzmanības centrā nonāca sociālistiskās sabiedrības morālie aspekti, seksuāls neizvēlīgums, alkoholisms un morāles normu pazemināšanās, tāpēc Polijas Tautas Republikā likumdošana bija vērsta pret prostitūtām un alkoholiķiem. Piespiedu izmeklēšana un hospitalizācija kḷuva par vienu no līdzekḷiem nevēlamas uzvedības izskaušanai. Vācijas Demokrātiskās Republikas tiesību aktos nebija iekḷauts šo grupu tiešs nosaukums. Tomēr piespiedu ārstēšana un ikdiena slēgtajās venerisko slimību nodaḷās liecina, ka pret grupām, kas neiekḷāvās sabiedrībā, īpaši jaunām sievietēm, tā sauktajām klaidonēm, tika pieņemti īpaši mēri. Daudzos gadījumos piespiedu hospitalizācija notika, pārkāpjot tiesiskos regulējumus. Pamatojoties uz šo iestāžu iekšējiem noteikumiem, venerisko slimību nodaḷās ievietotās sievietes, izmantojot medicīnisku iejaukšanos un iebiedēšanu, tika "pāraudzinātas", lai viṇas 
iekḷautos sociālistiskajā sabiedrībā. Nav zināmi līdzīgi pāraudzināšanas gadījumi Polijas Tautas Republikā.

Skaidri redzams, ka Vācijas Demokrātiskajā Republikā piespiedu ārstēšana tika galvenokārt piemērota sievietēm, kuras tika uzskatītas par klaidonēm, t. i., bez dzīvesvietas vai pastāvīgas darbavietas. Vācijas Demokrātiskajā Republikā prostitūtas veidoja pavisam nelielu procentu no kopējā pacientu skaita, savukārt vīriešus venerisko slimību nodaḷās ievietoja ḷoti reti. Literatūrā minēti līdzīgi pasākumi arī Polijas Tautas Republikā, tomēr ir jāveic detalizēta izpēte.

Venerisko slimību apkarošana kḷuva par politizētās medicīnas instrumentu, kas kalpoja arī komunistiskā režīma politiskās varas nostiprināšanai. Medicīnas politizāciju var pielīdzināt citām diktatūrām Eiropā. Attieksme pret veneriskajām slimībām un sabiedrības grupām, kas tika uzskatītas par sociāli bīstamām, un to salīdzinājums austrumu-austrumu un austrumu-rietumu perspektīvā vēl ir jāpēta.

This project of the Baltic-German University Liaison Office is supported by the German Academic Exchange Service (DAAD) with funds from the Foreign Office of the Federal Republic of Germany.

Marcin Orzechowski

Dr., Ulmas Universitātes Vēstures, filosofijas un medicīnas

ètikas institūts / Institute of the History, Philosophy and

Ethics of Medicine, Ulm University, Germany

Maximilian Schochow

PD Dr., Ulmas Universitātes Vēstures, filosofijas un medicīnas

ètikas institūts / Institute of the History, Philosophy and

Ethics of Medicine, Ulm University, Germany

\section{Florian Steger}

Dr., profesors, Ulmas Universitātes Vēstures, filosofijas un medicīnas ètikas institūts / Dr., Professor, Director of the Institute of the History, Philosophy and Ethics of Medicine, Ulm University, Germany 